\title{
Expression of interleukin $1 \beta$ and interleukin $1 \beta$ converting enzyme by intestinal macrophages in health and inflammatory bowel disease
}

\author{
M E McAlindon, C J Hawkey, Y R Mahida
}

\begin{abstract}
Background-In the lipopolysaccharide (LPS) stimulated peripheral blood monocyte, the precursor form of interleukin $1 \beta$

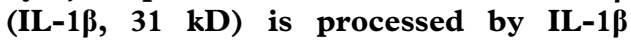
converting enzyme (ICE) to the mature, bioactive form $(17 \mathrm{kD})$. IL-1 $\beta$ is a proinflammatory cytokine which is likely to have a role in the pathogenesis of inflammatory bowel disease (IBD).

Aims-To investigate the expression and

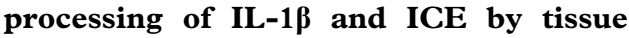
macrophages from normal and IBD colonic mucosa.

Methods-Mucosal biopsy specimens and lamina propria cells from normal and IBD colons were studied by reverse transcription polymerase chain reaction (RTPCR), western blot analysis, and ELISA (enzyme linked immunosorbent assay).

Results-Normal colonic macrophages synthesised only the precursor form of IL-1 $\beta$ whereas in IBD the mature form was also produced. Similarly, cells from normal colonic mucosa synthesised ICE as the precursor (p45) only, whereas macrophages from IBD colons produced active (p20) ICE. Ac-Tyr-Val-Ala-AspCHO, a specific peptide aldehyde inhibitor of ICE, significantly reduced the

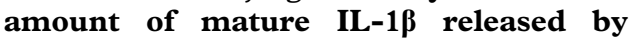
isolated IBD macrophages (from a me-

release of human IL-1 $\beta$ is best characterised in lipopolysaccharide (LPS) stimulated peripheral blood monocytes. These cells synthesise IL-1 $\beta$ initially as a $31 \mathrm{kD}$ biologically inactive propeptide which is released as the mature active $(17 \mathrm{kD})$ peptide following cleavage by IL-1 $\beta$ converting enzyme (ICE). ${ }^{3}{ }^{4}$ ICE is a cysteine protease which is synthesised as an inactive $45 \mathrm{kD}$ proenzyme ( $\mathrm{p} 45)$. Its enzymatic activity is mediated by two subunits, p20 $(20 \mathrm{kD})$ and p10 $(10 \mathrm{kD})$, which are cleavage products of the proenzyme. $^{5}$

In the mucosa affected by active inflammatory bowel disease (IBD), a large amount of mature IL- $1 \beta$ is produced. ${ }^{67}$ Studies of mucosal expression ${ }^{8}$ and on isolated cells ${ }^{9}{ }^{10}$ have shown that IL-1 $\beta$ is produced almost exclusively by intestinal macrophages. Cells isolated from normal colonic mucosa produce very little mature IL- $1 \beta,{ }^{10}$ despite stimulation with LPS. ${ }^{9}$ The inability of normal intestinal macrophages to produce mature IL- $1 \beta$ could result from regulation at one or more steps from gene activation to post-translational processing of the propeptide by ICE and release of the mature peptide. To investigate this further, we have studied the expression of messenger RNA (mRNA) transcripts and both precursor and processed forms of IL-1 $\beta$ and ICE in lamina propria macrophages isolated from normal and IBD colonic mucosa.
\end{abstract} dian of 1.2 (range $0.78-4.42$ ) $\mathrm{ng} / \mathrm{ml}$ to 0.43 (0.21-1.6) $\mathrm{ng} / \mathrm{ml}$; $\mathrm{p}<0.01)$.

Conclusions-Exposure of normal colonic macrophages to LPS only induces the production of the precursor form of IL-1及, because the cells fail to activate ICE. In contrast, IBD colonic macrophages are able to activate ICE and hence release

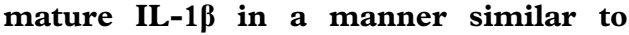
circulating monocytes. This is consistent with IBD macrophages being recently recruited from the circulating monocyte population. Targeted inhibition of ICE may represent a novel form of therapy in IBD.

(Gut 1998;42:214-219)

Keywords: interleukin $1 \beta$; interleukin $1 \beta$ converting enzyme; macrophages; lipopolysaccharide; ulcerative colitis; Crohn's disease

M E McAlindon

C J Hawkey

Y R Mahida

Correspondence to:

Dr Mahida.

Accepted for publication 5 September 1997

Interleukin $1 \beta$ (IL-1 $\beta$ ), a cytokine released predominantly by mononuclear phagocytes, is a key mediator in immunoregulatory and inflammatory processes. ${ }^{12}$ The processing and

\section{Methods}

COLONIC MUCOSAL BIOPSY SPECIMENS

Biopsy specimens were taken during colonoscopy from the sigmoid colon of adult patients with histologically normal mucosa $(n=13$; eight males; median age 57 years, range $30-85$ ) and those with active IBD (10 ulcerative colitis (UC), two Crohn's disease (CD); seven males; median age 50 years, range 32-66). Activity was defined macroscopically as grade 2 or worse (grade 0 , normal; grade 1 , erythema and loss of vascular pattern; grade 2 , contact bleeding; grade 3, spontaneous bleeding; and grade 4 , ulceration $)^{11}$ and was confirmed by histological examination. Patients with IBD were all taking 5-aminosalicylic acid preparations, either alone $(n=5)$ or with steroids $(n=3)$, steroids and azathioprine $(n=2)$, cyclosporin $(n=1)$, or metronidazole $(n=1)$. The study was approved by the Nottingham University Hospital Ethics Committee and all patients gave written, informed consent. 

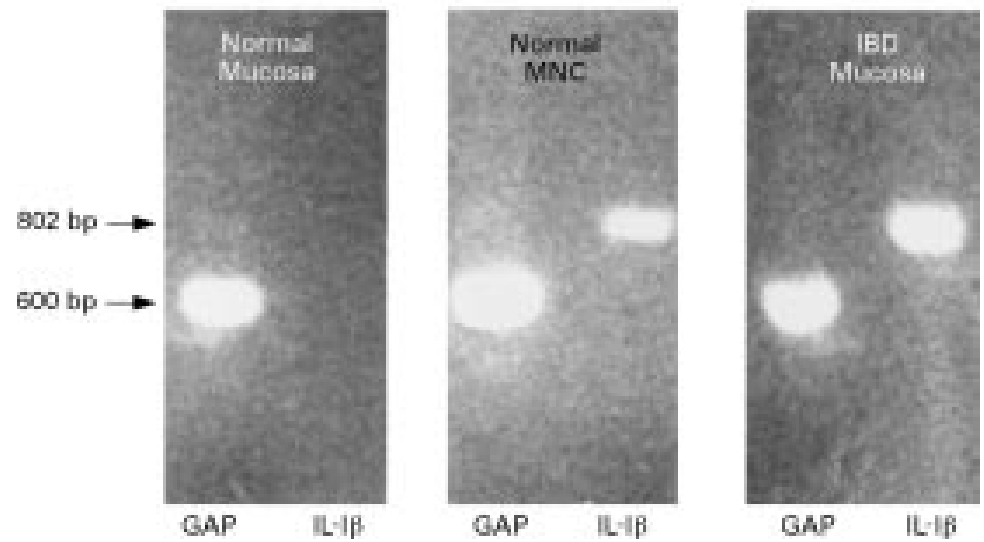

Figure 1 Expression of $m R N A$ transcripts for IL-1 $\beta$ and glyceraldehyde-6-phosphate dehydrogenase (GAP) in a normal colonic biopsy specimen; lamina propria mononuclear active IBD. The figure shows an example of 10/13 normal colonic biopsy samples which did not express transcripts for $I L-1 \beta$.

ISOLATION OF PERIPHERAL BLOOD MONONUCLEAR CELLS

Peripheral blood mononuclear cells were separated by centrifugation of human blood (from healthy volunteers) through lymphocyte separation medium (ICN Biomedicals Inc., Costa Mesa, California). The mononuclear cell interface was collected and washed three times in Hanks buffered salt solution (Gibco BRL). After the final wash the cells were resuspended in RPMI 1640 (Gibco BRL) containing 5\% fetal calf serum (FCS), the cells were counted, and viability was assessed by ability to exclude trypan blue (used at a final concentration of 4 $\mu \mathrm{g} / \mathrm{ml}$; Sigma).

ISOLATION OF LAMINA PROPRIA CELLS

Normal (at least $10 \mathrm{~cm}$ from tumour) and active IBD (seven UC, four CD) mucosal tissue was obtained from fresh colonic resection specimens. The median age of eight patients from whom normal tissue was ob-

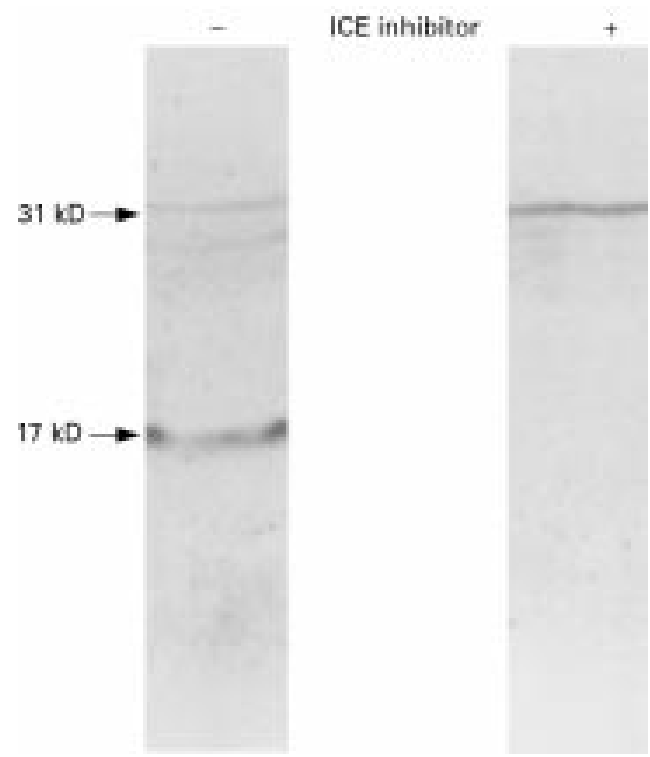

Figure 2 Expression of IL-1 $\beta$ protein in LPS stimulated peripheral blood mononuclear cell culture supernatants in the absence (-) and presence (+) of the ICE inhibitor, Ac-Tyr-Val-Ala-Asp-CHO. tained was 63 years (range 50-75), of whom five were male. The median age of the IBD patients was 44 years (range 20-62), of whom seven were male and all but one were being medically treated (with steroids alone $(n=1)$, 5-aminosalicylic acid preparations alone $(\mathrm{n}=4)$, both therapies alone $(\mathrm{n}=1)$ or with azathioprine $(n=1)$, cyclosporin $(n=1)$, or metronidazole $(n=1)$ ). In all IBD cases the indication for surgery was active disease refractory to medical therapy. Lamina propria cells were isolated using a new method. ${ }^{12}$ Briefly, mucosal strips were shaken at $37^{\circ} \mathrm{C}$ for three 30 minute periods in calcium and magnesium free Hanks balanced salt solution (Gibco BRL) containing $1 \mathrm{mmol} / 1 \mathrm{EDTA}$ (Sigma) to remove epithelial cells. The de-epithelialised mucosal pieces were subsequently cultured at $37^{\circ} \mathrm{C}$ in RPMI containing $10 \%$ FCS. During incubation, lamina propria cells emerged into the medium. After 24 hours the de-epithelialised mucosa was removed and cells in the culture dish collected following incubation at $4^{\circ} \mathrm{C}$ for one hour and vigorous washing to detach adherent cells.

CELL CULTURE STUDIES

Isolated cells $\left(5 \times 10^{6}\right.$ cells $\left./ \mathrm{ml}\right)$ were cultured at $37^{\circ} \mathrm{C}$ in $5 \% \mathrm{FCS} / \mathrm{RPMI}$ alone or with added bacterial LPS (Escherichia coli 055:B5, 10 $\mu \mathrm{g} / \mathrm{ml}$; Sigma). In some experiments, cells were cultured with both LPS and Ac-Tyr-Val-AlaAsp-CHO (final concentration $100 \mu \mathrm{M}$; Neosystem Laboratoire, Strasbourg, France), a specific peptide aldehyde inhibitor of ICE. ${ }^{4}$ After 20 hours, the cells and supernatants were collected for reverse transcription polymerase chain reaction (RT-PCR) and western blot analysis. For the latter, the cells were lysed by rapid freeze thawing three times and the lysates and supernatants stored (at $-70^{\circ} \mathrm{C}$ ) in the presence of protease inhibitors $(1 \mathrm{mM}$ phenylmethylsulphonyl fluoride, $1 \mathrm{mg} / \mathrm{ml}$ pepstatin, and $1 \mathrm{mg} / \mathrm{ml}$ leupeptin; Sigma) and $1 \mathrm{mM}$ EDTA. In the studies with the ICE inhibitor, the supernatants were also used for measurement of mature IL- $1 \beta$ by ELISA.

RT-PCR

RNA was isolated from mucosal biopsy specimens and isolated lamina propria cells using a guanidinium isothiocyanate-phenol:chloroform extraction method (Micro RNA Isolation Kit, Stratagene). The RNA was reverse transcribed to complementary DNA (cDNA) using oligo(dt) primers (Pharmacia Biotech Inc.) and moloney murine leukaemia virus reverse transcriptase (Stratagene). The cDNA was amplified by PCR using the following primer pairs: 5'-CCACCCATGGCAAATTCCATGGCA-3' (sense) and 5'-TCTAGACGGCAGGTCA GGTCCACC-3' (antisense; both from Stratagene) to amplify a $600 \mathrm{bp}$ glyceraldehyde-6phosphate dehydrogenase (GAPDH) product; 5'-ATGGCAGAAGTACCTAAGCTCGC-3' (sense) and 5'-TTGACTGAAGTGGTACG TTAAACACA-3' (antisense; both from Clontech Laboratories, Palo Alto, California) to amplify an $802 \mathrm{bp}$ IL-1 $\beta$ product; and 5'AACCCAGCCTATGCCCAC-3' (sense) and 

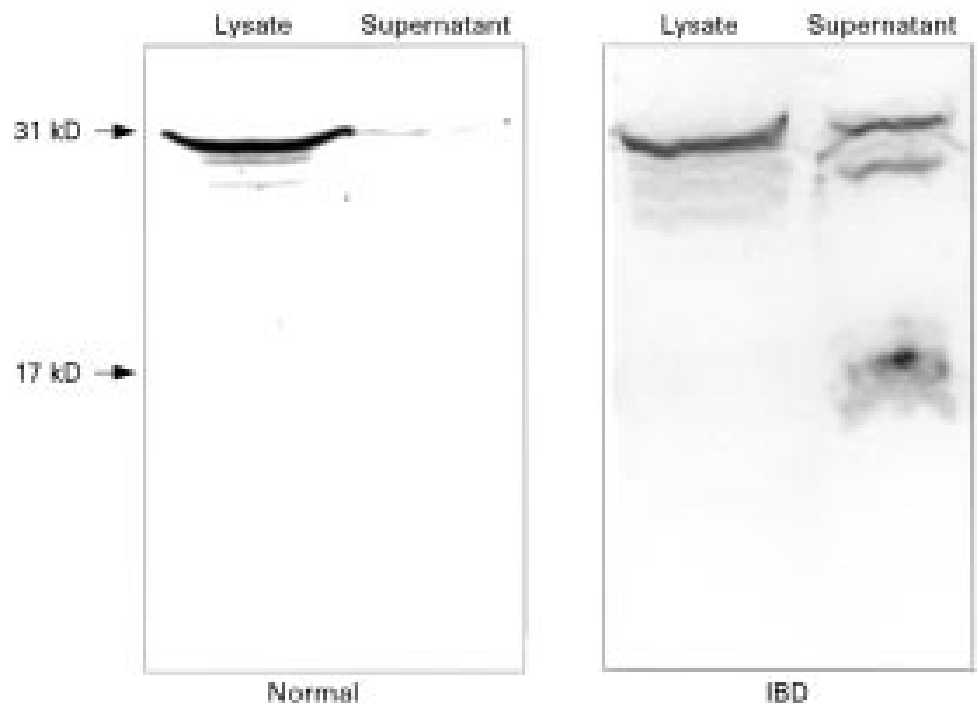

Figure 3 Expression of IL-1 $\beta$ protein by LPS stimulated lamina propria cells isolated from normal and IBD colonic mucosa. Cell lysates and supernatants were studied by western blot analysis. In cells obtained from IBD colon, both $31 \mathrm{kD}$ and $17 \mathrm{kD}$ forms of the cytokine were detected in the supernatants. The figure shows representative experiments performed on lamina propria cells obtained from four normal and five IBD colons.

5'-TGGGCTTTCTTAATAGC-3' (antisense) to amplify a $602 \mathrm{bp} \mathrm{ICE} \mathrm{product.} \mathrm{A} \mathrm{total} \mathrm{of} 30$ PCR cycles was used and the products were visualised on ethidium bromide stained $2 \%$ agarose gels. RNA, cDNA, and PCR products were stored at $-70^{\circ} \mathrm{C}$. The ICE primer pairs were synthesised in our institution, based on the published nucleotide sequence. ${ }^{4}$ Initial experiments showed that PCR products of the expected size were obtained using these primers from RNA isolated from the human monocytic cell line, THP.1, and peripheral blood mononuclear cells (unpublished data), which are known to express ICE. ${ }^{34}$ Finally specificity for ICE was confirmed by sequencing the PCR product obtained from an IBD cell isolate.

\section{WESTERN BLOT ANALYSIS}

Protein in cell lysates and supernatants was separated by sodium dodecyl sulphate polyacrylamide gel electrophoresis (SDS-PAGE) using a $15 \% / 5 \%$ gel (by the method of Laemmli $^{13}$ ) and transferred onto nylon (Hybond-N; Amersham International plc). Immunostaining was performed using rabbit antihuman IL-1 $\beta$ antibody which detects both pro- and mature peptide $\mathrm{K} 4.7,{ }^{14} 1 \mu \mathrm{g} / \mathrm{ml}$ (a gift from Dr Chaplin, Howard Hughes Medical Institute, St Louis, Missouri, USA), or ICE antiserum which recognises the p45 and p20 (but not p10; Dr H Allen, personal communication) subunits (BBC4, $1 \mu \mathrm{g} / \mathrm{ml}$; a gift from BASF Bioresearch Corporation, Worcester, Massachusetts, USA). Immunoblots for IL- $1 \beta$ were incubated with an antirabbit secondary

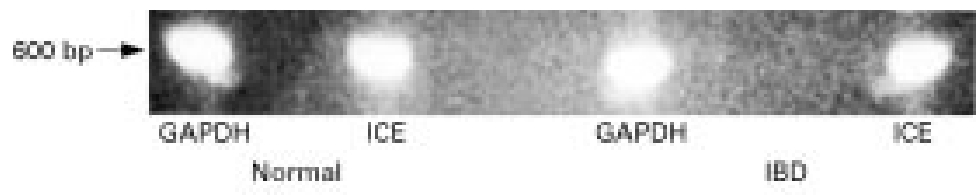

Figure 4 Expression of ICE and GAPDH mRNA in biopsy specimens from normal and IBD mucosa. antibody conjugated with alkaline phosphatase (Sigma) and developed using nitroblue tetrazolium and 5-bromo-4-chloro-3-indolyl-phosphate (from Promega). For detection of ICE protein, the Vectastain Elite ABC kit (Vector Laboratories) was used according to the manufacturer's instructions.

ELISA FOR IL-1 $\beta$

An enzyme linked immunosorbent assay (ELISA) that measures predominantly mature IL-1 $\beta$ (Quantikine IL-1 $\beta$ Immunoassay Kit, R\&D Systems Inc.) was used. Pro-IL- $1 \beta$ shows cross reactivity of up to $13 \%$ (20\% on a molar basis) in this ELISA.

\section{STATISTICS}

Analysis was performed by Fisher's exact test or paired Student's $t$ test. Data are expressed as mean (SEM) unless otherwise specified.

\section{Results}

ISOLATED PERIPHERAL BLOOD AND LAMINA

PROPRIA CELLS

Mean cell viability (assessed by trypan blue exclusion) of isolated peripheral blood mononuclear cells was 94.0 (3.4)\%.

Mean lamina propria cell viabilities from normal and inflamed mucosa were 92.6 (1.5)\% and 93.0 (3.3)\% respectively. There was no significant difference in the proportion of macrophages (CD68 positive) present in normal and IBD isolated cell preparations (10.5 (1.3)\% versus $8.4(0.9) \%$ respectively). Previous studies have shown that IL- $1 \beta$ is produced almost exclusively by intestinal macrophages ${ }^{8-10}$ and therefore cell separation was not performed.

\section{EXPRESSION OF IL- $1 \beta$ mRNA}

GAPDH mRNA (a constitutive marker) was expressed by all the samples studied. Of mucosal biopsy specimens from 13 normal colons, three expressed IL-1 $\beta$ mRNA, compared to all nine biopsy specimens from actively inflamed colons (seven with UC and two with $\mathrm{CD} ; \mathrm{p}<0.001$; fig 1 ). All isolated lamina propria cells from six normal and four IBD colons expressed IL- $1 \beta$ mRNA.

\section{EXPRESSION OF IL- $1 \beta$ PROTEIN}

To investigate the capacity of cells to translate IL-1 $\beta$ transcripts, western blot analysis of cultured cells was performed using an antibody that detects both pro-IL-1 $\beta$ and mature IL-1 $\beta{ }^{14}$ In supernatants of LPS stimulated peripheral blood mononuclear cells, both proand mature forms of IL- $1 \beta$ were present (fig 2 ).

Of four normal colonic lamina propria cell cultures, pro-IL-1 $\beta$ was identified in all cell lysates, three unstimulated culture supernatants and all four LPS stimulated cell culture supernatants (fig 3). However, the mature $17 \mathrm{kD}$ form of the cytokine was not seen in any of these samples.

Western blot analysis was also performed following culture (in the presence or absence of added LPS) of lamina propria cells isolated from active IBD mucosal samples obtained from five separate intestinal resection speci- 


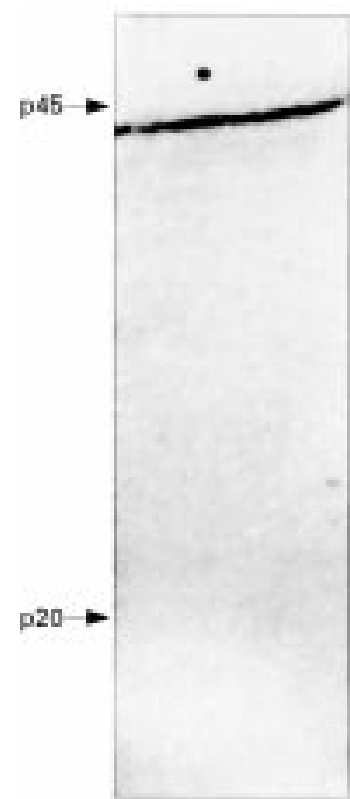

Normal

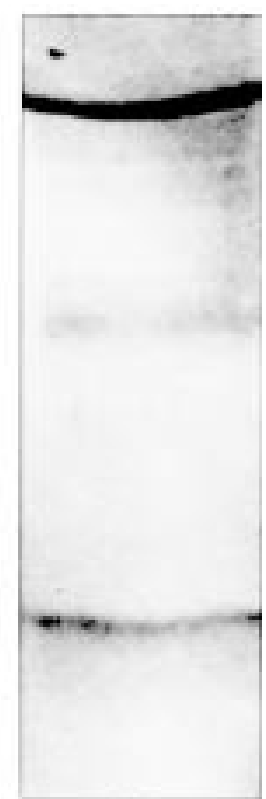

IED

Figure 5 Expression of ICE protein by LPS stimulated lamina propria cells isolated from normal and IBD colonic mucosa. In contrast to IBD, the p20 form of ICE was not present in the lysate of cells from normal colonic mucosa. The lighter band between $p 45$ and $p 20$ is likely to represent a $36 \mathrm{kD}$ intermediate cleavage product of $p 45$ (and which is further processed down to p20). ${ }^{38}$

mens. In all five LPS stimulated and four unstimulated cultures, both the $31 \mathrm{kD}$ and $17 \mathrm{kD}$ forms of IL-1 $\beta$ were present in the supernatant (fig 3 ). The cell lysates expressed pro-IL-1 $\beta$ only.

EXPRESSION OF ICE MRNA AND PROTEIN

The production of pro-IL- $1 \beta$, but not mature IL-1 $\beta$, by normal colonic macrophages could be explained by the lack of expression of ICE or

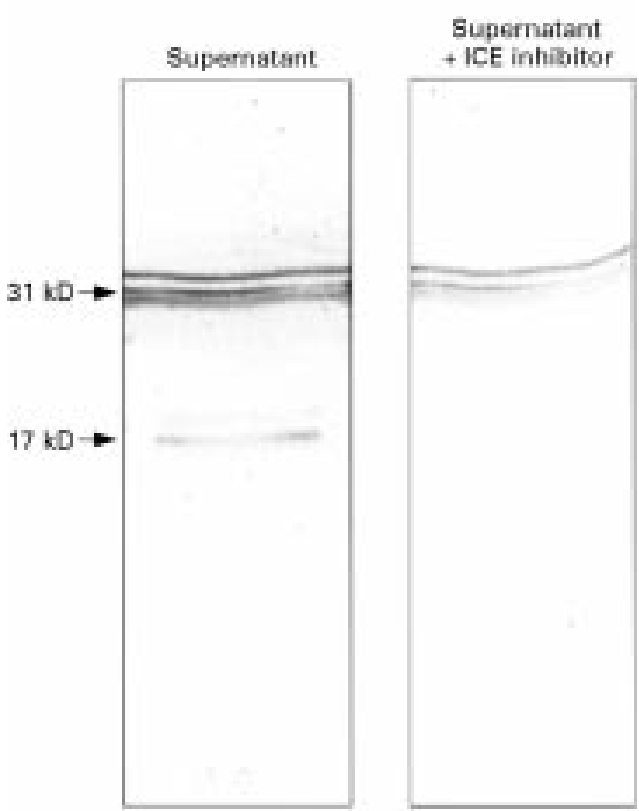

Figure 6 Release of IL-1 $\beta$ protein by IBD lamina propria cells cultured in the presence and absence of ICE inhibitor.

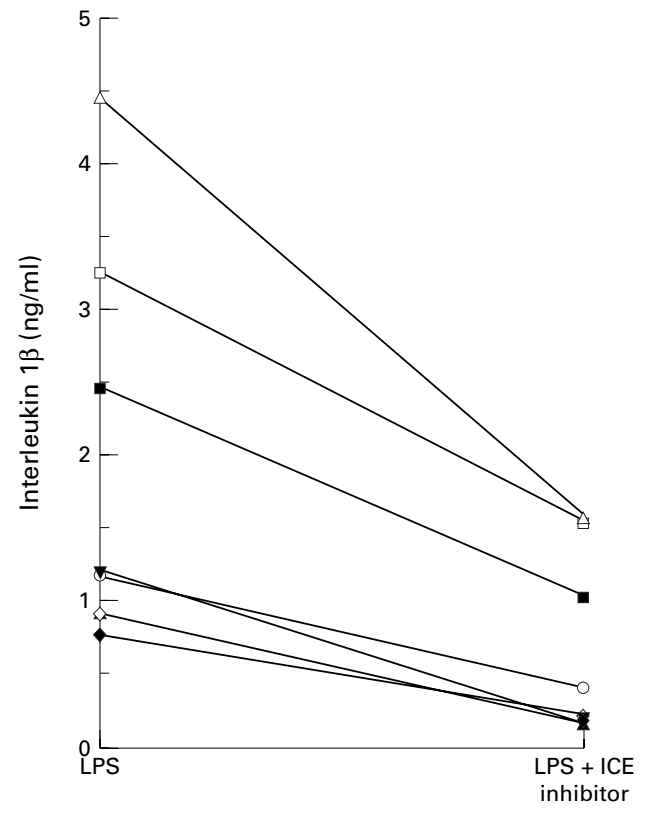

Figure 7 ICE inhibitor (Ac-Tyr-Val-Ala-Asp-CHO) reduces release of mature IL-1 $\beta$ by lamina propria cells isolated from mucosa with active IBD. Paired samples $(n=7)$ of isolated lamina propria cells were cultured with $L P S$, in the presence or absence of Ac-Tyr-Val-Ala-Asp-CHO.

the presence of ICE in biologically inactive form only. The expression of ICE transcripts and protein was therefore investigated.

Analysis by RT-PCR showed the presence of ICE transcripts in all mucosal biopsy specimens (12 normal and 11 active IBD; fig 4) and all isolated lamina propria cell preparations (six normal and three IBD). Western blot analysis of isolated lamina propria cell lysates (from four normal and four IBD colons) showed the presence of the p45 precursor form of ICE in all lysates. In all IBD, but not normal cell lysates, a large amount of the biologically active p20 ICE subunit was also present (fig 5).

EFFECT OF ICE INHIBITION ON RELEASE OF MATURE IL-1 $\beta$

Ac-Tyr-Val-Ala-Asp-CHO, a specific peptide aldehyde inhibitor of $\mathrm{ICE},{ }^{4}$ inhibited the release of mature IL-1 $\beta$ by LPS stimulated peripheral blood monocytes (fig 2). Similarly, western blot analysis showed that the mature $17 \mathrm{kD}$ form of IL-1 $\beta$ was not detected in supernatants of IBD lamina propria cells cultured in the presence of the ICE inhibitor (fig 6). The effect of the ICE inhibitor was also investigated by ELISA on seven paired samples of isolated lamina propria cells from mucosa with active IBD (fig 7). Cells cultured with LPS for 20 hours released a median of 1.20 (range $0.78-4.42$ ) $\mathrm{ng} / \mathrm{ml} \mathrm{IL-1} \beta$, which was significantly reduced in the presence of Ac-TyrVal-Ala-Asp-CHO to a median of 0.43 (range $0.20-1.60) \mathrm{ng} / \mathrm{ml} \mathrm{IL-1} \beta$ ( $\mathrm{p}<0.01$; fig 7 ). AcTyr-Val-Ala-Asp-CHO did not affect the viability of the isolated lamina propria cells (88.1 (4.2)\% preculture, and 89.8 (3.4)\% postculture). 


\section{Discussion}

In the lumen of the normal human colon, there is a large and complex resident population of microorganisms (approximately $10^{12} / \mathrm{g}$ contents), Gram negative bacteria being the predominant species. ${ }^{15}$ LPS, which is the outer membrane glycolipid of Gram negative bacteria, is a potent stimulator of IL- $1 \beta$ production by monocytes. Various other agents can induce the processing of pro-IL- $1 \beta$ by mononuclear phagocytes, but these are generally experimental stimulants which are not found in the normal colonic lumen. ${ }^{1416}$ LPS, however, is a physiological factor which is present in high concentration in the colon in close proximity to the mucosal cells; it has been implicated in the pathogenesis of active inflammatory bowel disease, ${ }^{17-19}$ and has been used in this and other studies ${ }^{14}{ }^{20}$ because of the exquisite sensitivity of mononuclear phagocytes to its effects. ${ }^{1}$

Previous studies have shown that IL- $1 \beta$ in the colon is expressed almost exclusively in the lamina propria macrophages ${ }^{8-10}$ and we have recently shown this to be the case for ICE. ${ }^{21}$ Our studies of IL-1 $\beta$ transcription have shown that normal colonic macrophages are capable of responding to isolation from the mucosa with activation of the IL- $1 \beta$ gene and that, in agreement with a previous report, ${ }^{22}$ a minority of normal colonic biopsy samples expressed IL-1 $\beta$ mRNA. In our cell isolation model, epithelial cells are first detached using EDTA, which will expose pores in the basement membrane, ${ }^{12}$ thus allowing access of LPS from residual luminal contents into the lamina propria in which macrophages are prominent. ${ }^{23}{ }^{24}$ We postulate, therefore, that it is the exposure to LPS which induces the expression of IL-1 $\beta$ in macrophages being isolated from normal mucosa. The findings of occasional IL-1 $\beta$ expression in apparently normal colonic mucosal biopsy specimens might be due to a similar process. LPS exposure could occur in vivo when injured or effete epithelial cells detach, temporarily allowing LPS to penetrate the lamina propria through basement membrane pores and stimulate the underlying macrophages. Our studies suggest, however, that on exposure to LPS, normal resident colonic macrophages are incapable of activating ICE and therefore cannot process proIL-1 $\beta$ to the biologically active form. This limitation of the macrophage response is likely to be important in avoiding inflammatory tissue injury provoked by penetration of the epithelium by LPS in the normal colon.

IL-1 $\beta$ mRNA was expressed in all biopsy specimens from colons affected by active IBD, a finding that might be explained by the increased LPS penetration of the epithelial barrier that occurs in active inflammatory bowel disease. ${ }^{17-19}$ In contrast to normal macrophages, however, IBD cells expressed active ICE and released both pro-IL-1 $\beta$ and mature IL-1 $\beta$. This is unlikely to be due to the treatment given to the patients as the drugs that may influence IL- $1 \beta$ production (prednisolone and 5-aminosalicylic acid) are likely to have opposite effects ${ }^{6}$ to those observed. Thus IBD colonic macrophages differ from normal co- lonic macrophages in being able to process pro-IL-1 $\beta$ in a manner similar to circulating monocytes. Our data would therefore also be consistent with previous studies suggesting that IBD macrophages are recently recruited peripheral blood monocytes, ${ }^{25-27} 35$ which are known to express ICE and readily process proIL-1 $\beta$ to the mature peptide following stimulation with LPS. ${ }^{1-5}$

ICE activity has been reported to be associated with apoptosis. ${ }^{28}$ However, more recent studies suggest that ICE is not essential for programmed cell death but that it is the sole enzyme responsible for processing of proIL-1 $\beta$ to the mature peptide in macrophages. ${ }^{29-31}$ Similarly, we have not found evidence of apoptosis in isolated and LPS stimulated IBD intestinal macrophages (unpublished data), consistent with a primarily proinflammatory role for active ICE expression in IBD.

Migration of circulating monocytes and polymorphonuclear cells into injured tissue is a characteristic feature of an inflammatory response. Recent studies suggest that in the colon, inflammatory responses may be initiated by epithelial cell secretion of chemokines, such as monocyte chemoattractant protein 1 (MCP-1) and IL-8, following invasion by pathogenic bacteria ${ }^{32}{ }^{33}$ or injury induced by bacterial toxins. ${ }^{34}$ As yet uncharacterised injury to epithelial cells, and subsequent release of chemoattractants, may also be responsible for initiating relapse in IBD. Our studies suggest that in the absence of epithelial cell injury, the resident colonic macrophages do not initiate an inflammatory response following exposure to LPS. Thus epithelial cell injury and secretion of chemokines and/or penetration of microorganisms into the lamina propria may be a prerequisite for the development of an inflammatory reaction in the intestinal mucosa. Monocytes recruited during this process would have the capacity, on exposure to luminally derived LPS, to release mature IL-1 $\beta$, which together with other cytokines and mediators (such as oxygen radicals ${ }^{35}$ ) could cause a cascade of tissue damaging inflammatory responses.

IL-1 $\beta$ itself is likely to be of major importance in the pathogenesis of IBD. Inhibition of its activity with a receptor antagonist has previously been shown to reduce the inflammatory response in an animal model of colitis. ${ }^{36}$ Our studies have shown that specific inhibition of ICE with a peptide aldehyde inhibitor leads to a significant reduction in the amount of mature IL-1 $\beta$ released. The magnitude of this reduction may be greater than our data suggest since the ELISA used to detect mature IL- $1 \beta$ cross reacts with pro-IL-1 $\beta$ (approximately $20 \%$ on a molar basis; information from R \& D Systems Inc.), the release of which increases following ICE inhibition. ${ }^{47}$ Agents that specifically inhibit ICE activity could therefore be of therapeutic value in patients with active inflammatory bowel disease.

This study was presented at the 96th Annual Meeting of the American Gastroenterological Association and has been 
published in abstract form (Gastroenterology 1996;110:A961). We thank Professor Savill for careful reading of the manuscrip and helpful suggestions. Dr McAlindon was supported by the British Digestive Foundation.

1 Dinarello CA. Interleukin-1 and its biologically related cytokines. Adv Immunol 1989;44:153-205.

2 Di Giovine FS, Duff GW. Interleukin 1: the first interleukin. Immunol Today 1990;11:13-20.

3 Cerretti DP, Kozlosky CJ, Mosley B, et al. Molecular cloning of the interleukin-1 $\beta$ converting enzyme. Science 1992;256:97-100

4 Thornberry NA, Bull HG, Calaycay JR, et al. A novel heterodimeric cysteine protease is required for interleukin-1 $\beta$ processing in monocytes. Nature 1992;356 768-74.

5 Wilson KP, Black J-AF, Thomson JA, et al. Structure and mechanism of interleukin- $1 \beta$ converting enzyme. Nature 1994;370:270-5.

6 Mahida YR, Lamming CED, Gallagher A, Hawthorne AB, Hawkey CJ. 5-Aminosalicylic acid is a potent inhibitor of interleukin- $1 \beta$ production in organ culture of colonic biopsy specimens from patients with inflammatory bowel biopsy specimens from pat
disease. Gut 1991;32:50-4.

7 Ligumsky M, Simon PL, Karmeli F, Rachmilewitz D. Role of interleukin 1 in inflammatory bowel disease-enhanced of interleukin 1 in inflammatory bowel disease-enhan
production during active disease. Gut 1990;31:686-9.

production during active disease. Gut 1990;31:686-9.
8 Cappello M, Keshav S, Prince C, Jewell DP, Gordon S. Detection of mRNAs for macrophage products in inflammatory bowel disease by in situ hybridisation. Gut 1992;33: 1214-9.

9 Mahida YR, Wu K, Jewell DP. Enhanced production of interleukin- $1 \beta$ by mononuclear cells isolated from mucosa with active ulcerative colitis or Crohn's disease. Gut 1989; 30:835-8.

10 Youngman KR, Simon PL, West GA, et al. Localisation of intestinal interleukin 1 activity and protein and gene expression to lamina propria cells. Gastroenterology 1993; 104:749-58.

11 Riley SA, Mani V, Goodman MJ, Herd ME, Dutt S, Turnberg LA. Comparison of delayed release 5 aminosalicylic acid (mesalazine) and sulphasalazine in the treatment of mild to moderate ulcerative colitis relapse. Gut 1988;29: mild to

12 Mahida YR, Galvin A, Gray T, et al. Migration of human intestinal lamina propria lymphocytes, macrophages and eosinophils following the loss of surface epithelial cells. Clin Exp Immunol 1997;109:377-86.

13 Laemmli UK. Cleavage of structural proteins during the assembly of the head of bacteriophage T4. Nature 1970;277:680-4

14 Hogquist KA, Unanue ER, Chaplin DD. Release of IL-1 from mononuclear phagocytes. F Immunol 1991;147:21816.

15 Simon GL, Gorbach SL. Normal alimentary tract microflora. In: Blaser MJ, Smith PD, Ravdin JI, Greenberg HB, Guerrant RL, eds. Infections of the gastrointestinal tract. New York: Raven Press, 1995:53-69.

16 Perregaux B, Gabel CA. Interleukin-1 $\beta$ maturation and release in response to ATP and nigericin. Evidence that potassium depletion mediated by these agents is a potassium depletion mediated by these agents is a necessary and common

17 Kruis W, Schussler P, Weinzierl M, Galanos C, Eisenburg J. Circulating lipid A antibodies despite absence of systemic endotoxaemia in patients with Crohn's disease. Dig Dis Sci 1984;29:502-7

18 Wellman W, Fink PC, Benner F, Scmidt FW. Endotoxaemia in active Crohn's disease: treatment with whole gut irrigation and 5-aminosalicylic acid. Gut 1986;27:814-20.

19 Gardiner KR, Halliday MI, Barclay GR, Milne L, Brown D, Stephens S, Maxwell RJ, Rowlands BJ. Significance of systemic endotoxaemia in inflammatory bowel disease. Gut 1995;36:897-901.
20 Mazlam MZ, Hodgson HJF. Peripheral blood monocyte cytokine production and acute phase response in inflammatory bowel disease. Gut 1992;33:773-8.

21 McAlindon ME, Hawkey CJ, Mahida YR. Interleukin-1 $\beta$ converting enzyme (ICE) is expressed by macrophages in the lamina propria of active inflammatory bowel disease (IBD) mucosa (abstract). Gut 1996;39(suppl 3):A93.

22 Isaacs KL, Sartor RB, Haskill S. Cytokine messenger RNA profiles in inflammatory bowel disease mucosa detected by polymerase chain reaction amplification. Gastroenterology 1992;103:1587-95.

23 Selby WS, Poulter LW, Hobbs S, Jewell DP, Janossy G. Heterogeneity of HLA-DR positive histiocytes in human intestinal lamina propria: a combined histochemical and imm
nohistological analysis. $\mathcal{F}$ Clin Pathol 1983;36:379-84.

24 Mahida YR, Patel S, Gionchetti P, Vaux D, Jewell DP. Macrophage subpopulations in lamina propria of normal and rophage subpopulations in lamina propria of normal and

25 Mahida YR, Patel S, Wu K, Jewell DP. Interleukin 2 receptor expression by macrophages in inflammatory bowel disease. Clin Exp Immunol 1988;74:382-6.

26 Grimm MC, Pullman WE, Bennett GM, Sullivan PJ, Pavli P, Doe WF. Direct evidence of monocyte recruitment to inflammatory bowel disease mucosa. $\mathcal{F}$ Gastroenterol Hepatol 1995;10:387-95.

27 Rugtveit J, Haraldsen G, Høgåsen AK, Bakka A, Brandtzaeg $\mathrm{P}, \mathrm{Scott} \mathrm{H}$. Respiratory burst of intestinal macrophages in , Scott $\mathrm{H}$. Respiratory burst of intestinal macrophages in monocyte derived cells. Gut 1995;37:367-73.

28 Miura M, Zhu H, Rotello R, Hartwieg EA, Yuan J. Induction of apoptosis in fibroblasts by IL- $1 \beta$-converting enzyme, a mammalian homolog of the $\mathrm{C}$. elegans cell death gene ced-3. Cell 1993;75:653-60.

29 Ping L, Allen H, Benerjee S, et al. Mice deficient in IL-1 $\beta$ converting enzyme are defective in production of mature IL-1 $\beta$ and resistant to endotoxic shock. Cell 1995;80:40111.

30 Nicholson DW, Ali A, Thornberry NA, et al. Identification and inhibition of the ICE/CED-3 protease necessary for mammalian apoptosis. Nature 1995;376:37-43.

31 Nett-Fiordalisi M, Tomaselli K, Russell JH, Chaplin DD. Macrophage apoptosis in the absence of active interleukin$1 \beta$-converting enzyme. $\mathcal{F}$ Leukoc Biol 1995;58:717-24.

32 Jung HC, Eckmann L, Yang S-K, et al. A distinct array of proinflammatory cytokines is expressed in human colon epithelial cells in response to bacterial invasion. F Clin Invest 1995;95:55-65.

33 Reinecker H-C, Loh EY, Ringler DJ, Mehta A, Rombeau JL, MacDermott RP. Monocyte-chemoattractant protein 1 gene expression in intestinal epithelial cells and inflammatory bowel disease mucosa. Gastroenterology 1995;108:4050

34 Mahida YR, Makh S, Hyde S, Gray T, Borriello SP. Effect of Clostridium difficile toxin $\mathrm{A}$ on human intestinal epithelial cells: induction of interleukin- 8 production and apoptosis cells: induction of interleukin-8 production and

35 Mahida YR, Wu KC, Jewell DP. Respiratory burst activity of intestinal macrophages in normal and inflammatory bowel disease. Gut 1989;30:1362-70.

36 Cominelli F, Nast CC, Clark BD, et al. Interleukin 1 (IL-1) gene expression, synthesis, and effect of specific IL-1 receptor blockade in rabbit immune complex colitis. $\mathcal{f}$ Clin Invest 1990;86:972-80.

37 Miller BE, Krasney PA, Gauvin DM, et al. Inhibition of mature IL-1 $\beta$ production in murine macrophages and a murine model of inflammation by WIN 67694, an inhibitor of IL-1 $\beta$ converting enzyme. F Immunol 1995;154:1331-8.

38 Ramage P, Cheneval D, Chvei $\mathrm{M}$, et al. Expression, refolding, and autocatalytic proteolytic processing of the interleukin-1 $\beta$-converting enzyme precursor. $f$ Biol Chem 1995;270:9378-83. 